\section{Lipoprotein Nature of Red Cell Adenosine Triphosphatase}

THE adenosine triphosphatase activity of stromata prepared from human red cells has recently been thoroughly investigated by Post et al. ${ }^{1}$ and by Dunham and Glynn'. The authors were able to demonstrate that in this ATPase, which is activated by magnesium and shows optimal efficacy at $p H$ 7, two fractions can be distinguished, one being activated by calcium and another being inhibited by calcium and activated by sodium and potassium. The part activated by sodium and potassium amounts to $30-50$ per cent of the total, and is further characterized by being inhibited by cardiac glycosides. It thus shows striking similarity to the ATPase present in submicroscopic particles isolatod from crab nerve sheaths as studied by Skou ${ }^{3,4}$. The dependence of these enzymes on sodium and potassium and their sensitivity towards cardiac glycosides strongly suggest that they play a part in the active transport of sodium and potassium through the cell mem. brane.

In 1950 Kielley and Meyerhof ${ }^{5}$ had isolated from rabbit muscle homogenates a fraction sedimenting at $18,000 \mathrm{~g}$ which displayed magnesium-activated, calcium-inhibited ATPase activity. This activity could partly be inhibited by treatment with an enzyme from Clostridium welchii, which removes phosphorylcholine from lecithin and likewise but at a slower rate from sphingomyelin.

In the experiments recorded here red cell ghosts, prepared from fresh human blood essentially according to the method of Post et al., were subjected to a similar treatment. A volume of $0.2 \mathrm{ml}$. of stromasuspension was added to $2.3 \mathrm{ml}$. of a fluid containing $12 \cdot 8 \mathrm{mM}$ imidazole-histidine buffer of $p H \mathrm{H} \cdot 1,16 \mathrm{mM}$ potassium chloride, $64 \mathrm{mM}$ sodium chlorido and 4.8 $\mathrm{mM}$ magnesium chloride. $1 \mathrm{mg}$ of a nucleic acid purified lecithinase from $C l$. welchii type $A$ culture filtrate was added to the samples, supplemented by $9.5 \mu$ moles calcium chloride. (The enzyme preparation was a generous gift by Dr. I. Batty, Wellcome Research Laboratories.) After $20 \mathrm{~min}$ incubation at $38^{\circ} \mathrm{C}$ the tubes were chilled in ice-water and the free Ca++ was removed by addition of $10 \mu$ moles of the tetrasodium salt of glycolether-diamine tetraacetic acid. Control samples showed that contact with calcium during $20 \mathrm{~min}$ and the presence of the complexing agent did not alter the ratio of glycosidesensitive to glycoside-insensitive ATPase, the average ratio from 6 experiments being 0.57 in the treated samples as compared with 0.6 in the controls. Afterwards the samples were incubated for $70 \mathrm{~min}$ at $38^{\circ} \mathrm{C}$ in the presence of 4.5 umoles ATP (disodium salt, Boehringer). In order to discriminate the fraction sensitive to sodium and potassium from the total ATPase activity $5.5 \times 10^{-5} \mathrm{M}$ g-strophanthin ('Ouabain', Merck) was added to one lecithinasetreated and one control sample respectively. After deproteinization with $2.5 \mathrm{ml} .10$ per cent trichloroacetic acid the liberated phosphorus was determined. by the method of Fiske and Subbarow. Since the lecithinase-treated samples gave a slight turbidity on addition of the molybdate reagent which was probably duo to formation of an insoluble compound with the liberated phosphorylcholine, the colorimetric measurement was carried out in the presence of about 50 per cent acetone which dissolved the precipitate. Acetone, however, gives a blue colour with the reagent, increasing in intensity over a long time. Therefore the readings were taken exactly 2 min after addition of the acetone.

Table 1 summarizes 6 experiments performed with two different blood samples, giving the ATPase activity as percentage of the controls treated in the same way except for the addition of lecithinase. It can be seen that both the glycoside-sensitive and insensitive fraction are reduced to about the same level by attack with lecithinase. Whether complete abolition could have been achieved by prolonged exposure to the lecithinase was not investigated. These experiments show that the integrity of the lipid component of the stromata is essential for the ATPase activity. Skou ${ }^{6}$ reported the abolition of the ATPase activity in crab nerve granules by treatment with phospholipase $A$, an observation pointing in the $\operatorname{sam} \theta$ direction.

\begin{tabular}{|c|c|c|c|}
\hline \multirow{2}{*}{ Blood No. } & \multirow{2}{*}{$\begin{array}{l}\text { Age of ghosts } \\
\text { (days) }\end{array}$} & \multicolumn{2}{|c|}{$\begin{array}{l}\text { Table } 1 \\
\text { ATPase activity of lecithinase-treated } \\
\text { ghosts (percentage of control) }\end{array}$} \\
\hline & & Glycoside sensitive & Glycoside insensitive \\
\hline 1 & $\begin{array}{r}7 \\
10 \\
11\end{array}$ & $\begin{array}{l}13 \cdot 3 \\
10.0 \\
48.5\end{array}$ & $\begin{array}{l}27 \cdot 6 \\
37 \cdot 5\end{array}$ \\
\hline 2 & $\begin{array}{c}11 \\
1 \\
3 \\
7 \\
\text { Average }\end{array}$ & $\begin{array}{l}48 \cdot 5 \\
1 \cdot 8 \\
33 \cdot 3 \\
66 \cdot 7 \\
28 \cdot 9 \\
P=0 \cdot 001\end{array}$ & $\begin{array}{c}48.0 \\
39 \cdot 2 \\
38.5 \\
38 \cdot 2 \\
P<0.001\end{array}$ \\
\hline
\end{tabular}

On the other hand, both fractions of the red cell ATPase can be blocked by the organic mercurial mersalyl. In an experiment with blood No. 2 of Table 1 the concentration of mersalyl for 50 per cent inhibition of both fractions was found to be about $4 \times 10^{-6} \mathrm{M}$. This brings out the fact that in the enzyme protein proper sulphydryl groups play a part, much as in the actomyosin ATPase?

The participation of the membrane lipids in the splitting of ATP can be visualized in different ways: (1) The lipid layer adjacent to the membrane proteins might help to stabilize the folding of the protein chains necessary for a good fit of ATP to the enzyme. (2) The characteristic phosphorylcholine group of lecithin and sphingomyelin, showing several negative charges in vicinity of the quaternary nitrogen, might fix the equally bipolar ATP molecule near the prosthetic group of the enzyme protein. (3) As suggested by Dunham and Glynn the enzyme responsible for the apparent splitting of ATP into ADP and phosphate might not liberate phosphate directly, but cause a transphosphorylation, the intermediary product undergoing subsequent hydrolysis. The phosphateaccepting substance might show liposolubility and be located in the lipid phase of the membrane. On destruction of the ordered array of the lipid molecules this acceptor might lose contact with the enzyme or even escape into the medium. It is an attractive hypothesis also advocated by Post ${ }^{8}$ that some of the phosphorylated intermediary product might serve as a carrier molecule for transport of sodium out of the cell.

Department of Pharmacology,

\section{H. J. SchatzmaNN} University of Berne.

${ }^{1}$ Post, R. L., Merritt, C. R., Kinsolving, C. R., and Albright, C. D., J. Biol. Chem., 235, 1796 (1960).

'Dunham, E. T., and Glynn, I. M., J. Physiol., 156, 274 (1961)

${ }^{3}$ Skou, J. Ch., Biochim. Biophys. Acta, 23, 394 (1957).

4 Skou, J. Ch., Biochim. Biophys. Acta, 42, 6 (1960).

${ }^{5}$ Kielley, W. W., and Meyerhof, O., J. Biol. Chem., 188, 391 (1950).

- Skou, J. Ch., Symp. Membrane Transport and Metabolism, Prague, 228 (1961)

7 Portzehl, H., Z. Naturforschg., 7, b, 1 (1952)

8 Post, R. L, (personal communication). 